\title{
Epstein-Barr Virus Related Multiple Cranial Nerve Neuropathy
}

\author{
Se-Joon $\mathrm{Oh}, \mathrm{MD}, \mathrm{PhD}^{1}$, Mi-Jin Mun, $\mathrm{MD}^{2}$, Soo-Keun Kong, $\mathrm{MD}, \mathrm{PhD}^{1}$ and Eui-Kyung Goh, $\mathrm{MD}, \mathrm{PhD}^{1}$ \\ ${ }^{I}$ Department of Otorhinolaryngology-Head and Neck Surgery, Pusan National University School of Medicine and \\ Biomedical Research Institute, Pusan National University, Busan: and \\ ${ }^{2}$ Department of Otorhinolaryngology-Head and Neck Surgery, Busan St. Marry's Medical Center, Busan, Korea
}

\section{- ABSTRACT -}

We present multiple cranial nerve paralysis including 6th, 7th and 8th cranial nerve in a 52-year-old woman with acute Epstein-Barr Virus (EBV) infection. While polyneuropathy has already been reported to be a potential sequelae for Epstein Virus infection, the specific combination of $\mathrm{CN} 6-8$ palsies has not been published although there have been reports of diplopia with other neuropathies in other reports. The information here would add much to the literature in managing several polyneuropathy. (J Clinical Otolaryngol 2017;28:225-227)

KEY WORDS : Epstein-barr virus infections · Cranial nerve diseases · Paralysis.

\section{Introduction}

The neurological complications are uncommon although it is estimated that 90 percent of humans worldwide has been infected by the Epstein-Barr virus $(\mathrm{EBV}) .{ }^{1)} \mathrm{EBV}$ is well known for infectious mononucleosis, lymphoproliferative disorders and malignancies such as Burkitt's lymphoma, and an approximately 0.37 percent infectious mononucleosis progress neurologic complications. ${ }^{2,7)}$ Here, we present multiple cranial nerve paralysis including 6th, 7th and 8th cranial nerve in a 52-year-old woman with acute EBV infection. This has not been reported in the literature, therefore it is important to recognize the presentation and possible complications of the disease. Approval for this report was granted by Institutional Review Board, and

논문접수일 : 2017년 8월 16일

논문수정일 : 2017년 9월 19일

심사완료일 : 2017년 10월 20일

교신저자 : 고의경, 49241 부산광역시 서구 구덕로 179

부산대학교 의학전문대학원 이비인후과학교실

전화 : (051) 240-7335 ·전송 : (051) 246-8668

E-mail:gohek@pusan.ac.kr we received the informed consent from the patient.

\section{Case Report}

A 52-year-old female visited our clinic due to sore throat and throbbing facial pain and heating sense of left side. She developed ear fullness and hearing disturbance on left ear after two days. The initial local findings showed hyperemic tympanic membrane, and air-fluid level of tympanic membrane was also observed. Moreover, asymmetric left tonsillar hypertrophy with exudate was identified. Myringotomy and culture were applied and broad-spectrum antibiotics was administered under the impression of left acute tonsillitis with acute otitis media, but an additional symptom, left side facial palsy (House-Brackmann grade III) occurred the next day. She was admitted to steroid treatment and more evaluation for her facial palsy. On day 3 after admission she developed the left abducens nerve palsy, evidenced by limitation of lateral gaze of left eye (Fig. 1). Magnetic resonance imaging (MRI) and computed tomography (CT) revealed that there are no underlying structural abnormalities, such as petrous apicitis, meningitis and other focal lesions. 

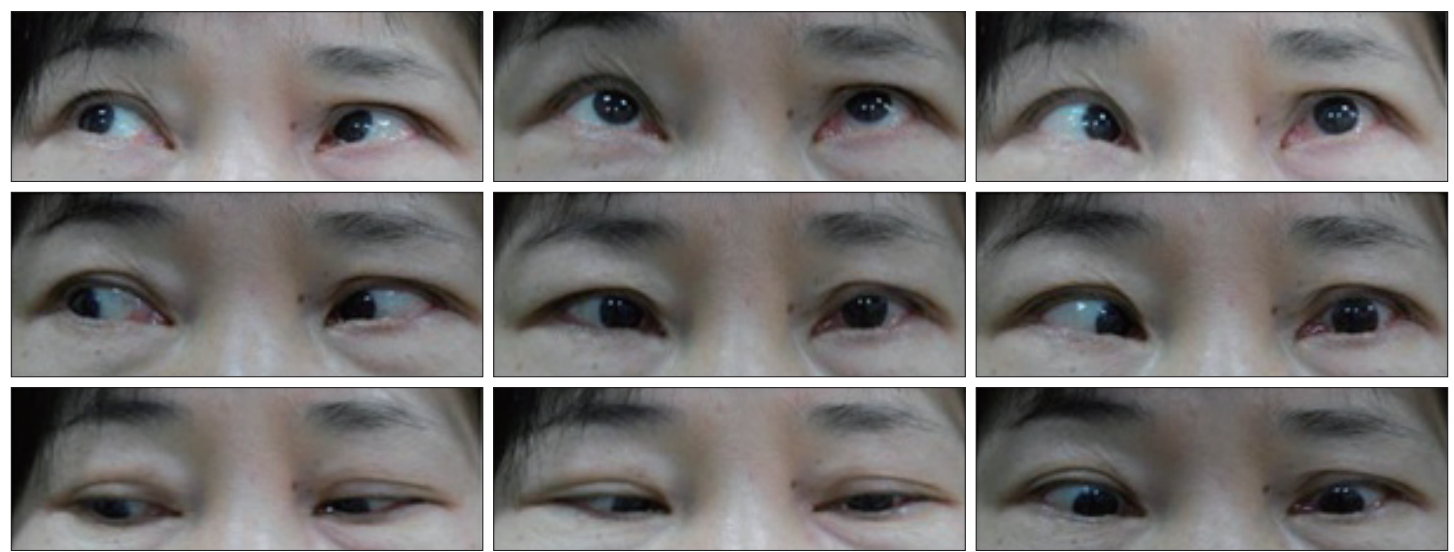

Fig. 1. The limitation of lateral gaze of left eye suggesting 6th cranial nerve palsy.
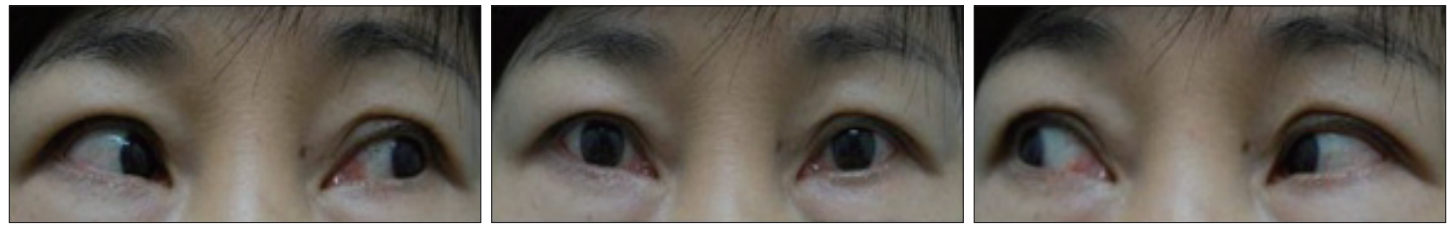

Fig. 2. Bilateral lateral gaze was possible at 4 month follow-up.

Since there was no definite lesion on imaging study, we suspected viral infection which could cause progressive multiple cranial nerve palsy. Cerebrospinal fluid analysis showed no specific abnormalities. However, serologic examination showed positive immnunoglobulin $\mathrm{G}$ and immnunoglobulin M for EBV. Pure tone audiogram and caloric test revealed sensorineural hearing loss of $31 \mathrm{~dB}$ and canal paresis of $37 \%$ weakness on left side implied the vestibulocochlear nerve neuropathy.

During admission, she was administered steroid, antiviral treatment besides other routine therapy for facial palsy. For ten days after the therapy, She felt comfortable, dizziness was controlled but hearing showed no improvement until discharge date. At review for four months after admission, most of her symptoms had been completely subsided except high frequency steeply sloping hearing loss (Fig. 2).

\section{Discussion}

Several diseases of CNS are associated with Epstein-
Barr virus infection, including encephalitis, meningitis, Guillain-Barré syndrome, myeloradiculitis and encephalomyeloradiculitis. ${ }^{3)}$ The incidence of neurologic involvement was reported as $0.37-7.3 \%$. Cranial neuropathies are not common in the acute EBV infection, and the pathogenesis of EBV-related neuropathy is not yet completely understood, but a direct invasion of virus to the neural tissue, or immnunologically mediated, being caused by the cytotoxic $\mathrm{CD} 8+$ cells infiltration into the nervous system are suggested. ${ }^{4)}$

Much of the involvement of the cranial nerves has been reported in relation to $\mathrm{EBV}$, the facial nerve being the most common. ${ }^{2)}$ Concomitant cranial nerve palsy of 7th and 8th are not uncommon considering their relatively close anatomic location, but additional 6th nerve palsy is rare and may indicate the lesion involving petrous apex such as Gradenigo's syndrome (suppurative otitis media, pain in trigeminal nerve distribution, abducens nerve palsy), however Gradenigo's syndrome was ruled out because CT scan and MRI failed to show any relevant lesion and the result of culture from middle ear discharge did not show any bac- 
terial growth. Neuroimaing studies such as MRI, CT in patients with EBV-associated neuropathies are mandatory for detecting the virus-associated cranial nerve enhancement and the excluding malignancy. ${ }^{5}$ It is assumed that CT, MRI may show increased signal intensity with contrast medium on cranial nerves affected by EBV infection because of hypervascularity of the nerve and/or disruption of the blood-brain barrier. ${ }^{2)}$

In primary EBV infection, the initial marked serological response is a rise for immunoglobulin $\mathrm{M}$ antibody (Ig M) against virus capsid antigen (VCA). Similar to VCA IgG, antibodies against EBV nuclear antigen (EBNA) appears at least 1 month after primary infection and persists for many years or throughout life. Consequently, both anti-VCA IgG and anti-EBNA IgG are indicators of prior infection, ${ }^{3)}$ therefore, it can be suspected that our patient was exposed to EBV for a month. Besides IgM antibody, asymmetric tonsillar hypertrophy with exudate strongly suggested the EBV infection. The CSF analysis can be helpful, but a clinician should be careful with the interpretation because abnormal results also can be found in EBV-infected individuals without neurological defect. Resolution of the symptoms takes generally $2-3$ weeks post-onset. Complete resolution can occur anywhere from 8 weeks to 7 months. $^{2)}$

The treatment of EBV-associated neurologic complications can be medical or surgical management.
Medical treatment is active supportive care which is necessary against another secondary complications. Supportive care is mainly composed of rest and rehydration, however there have been debates on the efficacy of steroids and antivirals. ${ }^{2,6)}$ Careful follow-up is strongly recommended although resolution over time is expected.

\section{REFERENCES}

1) Gavin C, Langan Y, Hutchinson M. Cranial and peripheral neuropathy due to Epstein-Barr virus infection. Postgrad Med J 1997;73(861):419-20.

2) Thomas A, Kong K. An unusual case of Epstein-Barr virus complicated by multiple cranial nerve neuropathy. Otolaryngol Head Neck Surg 2010;143(5 suppl 3):S38-9.

3) Volpi A. Epstein-Barr virus and human herpesvirus type 8 infections of the central nervous system. Herpes 2004; 11 Suppl 2:120-7.

4) Kaji M, Shoji H. Detection of Epstein-Barr virus genome in peripheral leucocytes and CSF by the polymerase chain reaction in two patients with Epstein-Barr virus related to aseptic meningitis. J Neurol Neurosurg Psychiatry 1995; 59(1):99.

5) Lehrnbecher T, Chittka B, Nanan R, Seidenspinner S, Kreth HW, Schuster V. Activated T lymphocytes in the cerebrospinal fluid of a patient with Epstein-Barr virus-associated meningoencephalitis. Pediatr Infect Dis J 1996;15(7): 631-3.

6) Long CM, Kerschner JE. Parotid mass: Epstein-Barr virus and facial paralysis. Int J Pediatr Otorhinolaryngol 2001; 59(2):143-6.

7) Lee YS. Nasopharyngeal carcinoma and Epstein-Barr virus. J Clinical Otolaryngol 1996;7(1):101-11. 